\title{
Factors Influencing Ponzi Scheme Participation In Nigeria
}

\author{
Professor Tomola Marshal Obamuyi \\ Department of Economics, School of Management Technology, \\ Federal University of Technology, Akure, Nigeria
}

Grace Oluwabukanla Iriobe

Department of Financial Studies, College of Management and Social Sciences, Redeemer's University, Ede, Nigeria

Taofeek Sola Afolabi

Department of Financial Studies, College of Management and Social Sciences, Redeemer's University, Ede, Nigeria

\section{Akinpelu Denis Akinbobola}

Department of Banking and Finance, Faculty of Social and Management Science, Adekunle Ajasin University, Akungba-Akoko, Ondo State, Nigeria

\section{Adegboyega John Elumaro}

Department of Banking and Finance, Faculty of Social and Management Science, Adekunle Ajasin University, Akungba-Akoko, Ondo State, Nigeria

\section{Bukola Akintade Faloye}

Department of Banking and Finance, Faculty of Social and Management Science, Adekunle Ajasin University, Akungba-Akoko, Ondo State, Nigeria

\section{Ademola Felix Adeyefa}

Department of Accountancy, Rufus Giwa polytechnic,

Owo, Ondo State, Nigeria

\section{Titilope Francis Adepoju}

Department of Project Management Technology, School of Management Technology, Federal University of Technology, Akure, Nigeria

\section{Anthonia Olabisi Oni}

Department of Project Managemnt Technology, School of Management Technology, Federal University of Technology, Akure, Nigeria

\section{ABSTRACT}

This study examined the factors influencing Ponzi scheme participation in Nigeria. A multi-stage sampling procedure was used to select 384 participants for the study. Descriptive statistic and One-Way ANOVA was employed to analyze the data. The result of the analysis revealed that friends' recommendation, expected benefits, current economic situations, ease of obtaining funds and the get rich quick syndrome were the most influencing factors on Ponzi scheme participation and these factors were significant with the gender, age, marital status, employment status and educational level at $5 \%$ level of significance. The study concluded that ponzi scheme participation was mostly influenced by friend's recommendation, expected benefit, current economic 


\begin{abstract}
situations, ease of obtaining funds and the Get rich quick syndrome. Therefore, the study recommended that the Nigerian government should integrate Ponzi schemes into the Nigerian financial system and subject them to the country's regulatory environment to minimize the consequences of future failure of the schemes.
\end{abstract}

Keywords: Ponzi scheme participation, Friends' recommendation, Expected benefits, Economic Situations, Get rich quick syndrome

Word Count: 152

\title{
INTRODUCTION
}

Ponzi schemes have been around in different forms since it was popularized in 1919 by Charles Ponzi. Mr Ponzi's method has continuously been used worldwide by other ponzi lovers. A popular scheme in the United State was Bernand Madoff in 2008. Nigeria has not been left out and has had her own share of the ponzi experience.

In November 2015, a widely known Ponzi scheme was launched in Nigeria called MMM Nigeria, over 2.4 million Nigerians participated in it till late 2016. The scheme promised to pay "30\% per month" returns including other accruable bonuses to all members that were involved in the scheme. The scheme was self-described as a "mutual aid fund" where ordinary people help each other (Kashi, 2017). Mutual funds involve voluntarily reciprocal exchange of resources for mutual benefits of participating members. The question that arises is whether ponzi schemes can be included in the formal financial system. According to Obamuyi (2002), Nigeria financial system comprises not only banks and non-bank financial institutions but also the financial markets, financial instruments and financial services.Asogwa, Etim, Etukafia, Akpanuko and Ntiedo (2017) defined Ponzi scheme as a financial investment that yields uncharacteristically high return on investment based strictly on conscious and serious hunt for admission of new members bearing little or no risk at all. The US Securities and Exchange Commission, as reported by Asogwa et al. (2017) defined Ponzi scheme as an investment fraud which involves payment of supposed yields to current investors from funds paid by fresh investors.

Carvajal, Moroe, Wynter and Pattillo (2009) summarised the several negative consequences of Ponzi schemes on the financial system to include: diversion of deposits and increased nonperforming loans, particularly loans diverted to Ponzi schemes; diversion of savings from productive to unproductive use, capital flight from domestic economy to foreign destinations; and erosion of confidence in the financial market. Other consequences of Ponzi schemes identified other than their effects on the financial system are: socio-economic discord if adequately large number of families or participant are unexpectedly exposed to losses; bad reputation for government and regulatory authorities for failure to prevent open frauds (Carvajal et al., 2009); increased burglary and theft in environment with weak law enforcement institutions and lesser access to credit (Cortes, Santamaria \& Vargas, 2016).

A shaky investment structure like this has seemingly attracted many Nigerians with individuals putting up to millions of Naira into the system. The question however, is what are the factors influencing participation in the scheme? Scholars such as Jarvis (2000), Gregoriou and Lhabitant (2009), Smith (2010), and, Drew and Drew (2010) have not only studied the various cases of failed schemes, but have attempted to identify the motivations behind people's involvement in new ones despite its high level of risk and loss of money invested. Nevertheless, none of the study above was embarked on in Nigeria to the best of our knowledge. Considering the fact that ponzi schemes are relatively new in Nigeria, it becomes imperative to examine the factors responsible for the participation in the scheme and what influence this scheme has on the Nigerian financial system which this study seeks to achieve. 


\section{GENERAL OVERVIEW OF PONZI SCHEMES}

\section{Mode of Operations of the Five Popular Ponzi Schemes in Nigeria}

The study identified one hundred and five (105) ponzi schemes operated in Nigeria as at December, 2017 out of which five most popular were selected for the study. These include; MMM Nigeria, TwinkAS, Ultimate Cycler, ICharity and Get Help Worldwide. Their modes of operations are discussed below.

MMM Nigeria (Mavrodi Mondial Movement):-Members make pledges to donate their "SPARE" money to other members who need the money. The scheme promises a 30\% return on investment to members, after 30 days and $40 \%$ to $50 \%$ after 90 days. This return is in form of getting help from other participants. The system connects each member with the person in the queue for providing help. The common slogan under this platform is 'Provide Help' (PH) and 'Get Help' (GH).

TwinKAS: Is a system of peer to peer payment. It works in the form of donations from one member to another. To register in TwinKAS, prospective member will have to choose one of the four packages to get $100 \%$ return within 1-21days. These packages are classic, professional, premium, and ultimate.

Ultimate Cycler: This operates as a pyramid scheme. To register, a new member will have to donate the sum of $\$ 12,500$ to an existing member, whom he registered under. After confirmation of donation by the existing member, the system will allocate four other members from spill-overs, to the new members. These four members will also donate $\$ 12,500$ each into the specified bank account of this new member, totalling $\$ 50,000$. After receiving the $\$ 50,000$ donation, members are allowed to upgrade to Grade 2, by donating $\$ 25,000$ to an up-line grade 2 member. At this stage, and after confirmation by the up-line member, the system connects the new Grade 2 member with sixteen other members who will pay $\$ 25,000$ each, making $\$ 400,000$. The cycle continues this way. Members are also allowed to bring people to register under them, if they cannot wait for the system to do the allocation.

Icharity:- International Charity Club (ICharity Club) is an International network of donors. Icharity Club is a peer-to-peer donation platform for members to help other members in a systematic way. A new member registers for free and donates $\$ 6,000$ to an up-liner to become a Grade 1 member in the system. Thereafter, the system will locate and connect this individual to five free members, who will in turn donate $\$ 6,000$ each to him. Starting from Grade 1 , members can earn $\$ 30,000$ to Grade 2 where they earn $\$ 150,000$ and Grade 3 where they can earn $\$ 750,000$, and so on. In summary, the operation involves registering as free members and donating $\$ 6,000$ to upgrade to a Grade 1 member, in order to receive $\$ 30,000$ back as donations. The same happens in other grades where members get five times their donation.

Get Help Worldwide:- In the case of GHW, whatever help you give to someone financially grows by $30 \%$ if in local currency or $50 \%$ if in Bitcoin in 30 days. Help provided will grow at the rate of $30 \%$ for Local Currency or $50 \%$ for Bitcoin in 30 days. Credibility Index is a logical system where the community ensures the fair play basis. Each new account gets 100\% credibility. If you get help from the community, you should reinvest the sum of money no less than the help you have been provided. For example, if you've got from the community $\$ 1000$, you should reinvest the sum no less than $\$ 1000$. When you ve received help from the community, you should reinvest the sum of money no less than the help you have been provided in $48 \mathrm{hr}$. If you fail to do so, then you will be banned from the community.

One major similarity in the mode of operation of these five popular ponzi schemes in Nigeria is the fact that a new member will always contribute to the benefit of an existing or old member. 
This agrees with the definition of a ponzi scheme, put forward at the beginning of this write-up. Thus, a scheme is expected to come to a halt, when the supposed new member does not surface.

\section{Reasons for the Existence of Ponzi Schemes in Nigeria}

The discussion on what motivates people to get involved in Ponzi schemes has not gained much attention in literature. According to a study by Asogwa, et al (2017), the state of the economy of a nation plays a role in the existence or otherwise of ponzi schemes. They found a strong negative relationship between Nigerian economy and the growth of ponzi scheme. They believe that poor economic situation of any country can either encourage or discourage the existence of ponzi schemes. Some of the economic activities include decrease in gross domestic product, high inflation rate, high unemployment rate etc. When these factors are prevalent in an economy, people look for alternative means of earning more money. This position is debatable because they imply that the growth of economic activities leads to a drop in ponzi schemes activities. However, people also invest in ponzi schemes for speculative reasons, and when there is sufficient money within the economy (Rowe 2000).

Omanyo, (2017) deduced that lack of a strong legal and regulatory environment contributes to the operation of ponzi schemes in African economies. Irrespective of the environmental factors identified, scholars have identified greed as a major motivation for the growth of ponzi schemes (Asogwa et al, 2017; Rowe 2000). The expectation of receiving higher rates of returns and getting quick money has been one of the motivating factors in ponzi scheme involvement. Ponzi schemes take various forms and ponzi promoters are quick to adopt new financial instruments to perpetuate their act (Bartoletti, Carta, Cimoli \& Saia, 2017; Rowe 2000). For instance, new financial instruments like Blockchain and smart contract provides fraudsters the opportunity to experiment their ponzi scheme activities on a new demography (Bartoletti et al 2017; Slattery 2014). In Nigeria, some of these new financial instruments are not yet popular. However, the recent recession experienced in Nigeria has been identified as the major reason why ponzi schemes flooded the economy.

Furthermore, Azim and Azam (2016) opined that the presence of motivation, opportunity and rationalization elements stimulates participants' involvement in ponzi schemes. Of these three elements motivation is seen to explain the reasons why people put money in ponzi schemes. Motivation is seen to have arisen due to financial problems such as gambling addiction, accumulated debt, unexpected debt, and unexpected expenditures (Buchholz, 2012); and nonfinancial problems like the advancement of personal social standing which is mostly due to peer-pressure and personal status (Day, 2010). Other reasons for the existence of ponzi scheme include lack of financial market experience and information, weaknesses in governmental leadership, absence of a complete legal framework, new investment instruments and inappropriate inherited public expectations (Thanasi and Riotto, 2017).

\section{Reasons for the Failure of Ponzi Schemes}

Previous scholars (Jarvis 2000; Gregoriou \& Lhabitant 2009; Smith 2010; Drew \& Drew 2010) who have studied Ponzi scheme and its activities identified some causes of its collapse. Jarvis (2000) examined the rise and fall of Albania's Pyramid Scheme and observed that, the primary cause of the fall of the scheme was negative comments by press which began to discourage the decisions of new investors/participants thereby, leading to failure on the part of the scheme to meet up with the redemption of existing participants. As a result of the negative media publicity, the government of Albania started to move against some of the companies operating the ponzi schemes and refused to compensate depositors who lost their money in the scheme. Furthermore, the Bank of Albania began to limit daily withdrawals from bank accounts and 
finally, in February 1997, parliament passed a law banning the activities of pyramid schemes in Albania.

In the same vein, Gregoriou and Lhabitant (2009) investigated the Madoff's ponzi scheme, and discovered that, lack of due diligence was a major factor that led to the collapse of the scheme. Some investors thought the promised returns were too attractive to be neglected or Madoff was too respectable to be investigated. Other participants were assured by the testimonies of relatives and friends leading to the rush into the scheme while also, neglecting due diligence. Consistent with this view are Smith (2010) and Drew and Drew (2010).

Rhee (2009) analyzed the Madoff Ponzi Scheme and pointed out that, the scheme collapsed as a result of a steady flow of redemption. That is, participants continually request for their money which outweighed new funds. Also, Cherry and Wong (2009) concluded that, the fall of ponzi schemes like those of AIG and Merrill Lynch, Madoff etc. was primarily a result of "executive compensations". This could be seen in the case of MMM Nigeria, where there were numerous bonuses such as referral bonus, $10+$ guiders bonus, $100+$ guiders bonus, $1 \mathrm{~m}+$ guiders bonus among others.

Operational factors responsible for the collapse of ponzi schemes in Nigeria are unsustainable return on investment, greed by investors and founders, and administrative incompetence of support staff. Most ponzi schemes in Nigeria promised as high as 300\% returns on investment leading to creation of multiple accounts by greedy investors thereby creating pressure on the system. The pressure created lead to several complaints by investors which support staff could not handle.

\section{The Consequences of Ponzi Schemes' Failure in Nigeria}

A major consequence of failure of ponzi schemes is depletion of deposit in the banking system. Investors withdraw money from their savings from banks and put into the scheme with the aim of obtaining higher returns. In the occurrence of the failure of this scheme, the funds were lost and that could lead to loss of capital formation which may hamper economic growth in the country. Hofstetter et al (2017) found that the operation of ponzi schemes reduced municipal savings deposits by $2.9 \%$ and certificate of deposit by about $10 \%$ in Colombia as participant in Ponzi schemes withdraw their deposit to invest in Ponzi schemes. According to Simon (2017), prior to system collapse, Nigerians lost $\$ 18$ billion to MMM in 2016 through about three million participants in the scheme. Although some authors argued that the effect is minimal because all transactions of the schemes were assumed to be done through the banks and as such money were considered not to have been moved out of the banking system but these authors failed to consider what happened to the money lost in the event of collapse of the scheme.

As Cortes, Santamaria and Vargas (2016) noted, survival strategies (armed robbery, cybercrimes, frauds etc.) increase when ponzi schemes collapsed. Carvajal et al (2009) noted that the collapse of ponzi schemes lead to socio-economic discord, if adequately large number of families is unexpectedly exposed to losses as well as bad reputation for government and regulatory authorities for failure to prevent open frauds

The collapse of ponzi schemes have also led to increase in loss of lives and suicidal attempt in Nigeria. In 2016, when MMM announced its temporary closure, the youth being the mostly affected reacted differently, it was reported that some participants committed suicide in Lagos, Abuja and Nsukka after they lost money to the scheme (Fatunde, 2017). 
Furthermore, the collapse of ponzi schemes may have increased bad debt for banks in Nigeria. Hofstetter et al (2017) observed that operation of Ponzi schemes has the tendency of increasing loan and non-performing loans created by the formal financial sector. Using DMG and DRFE schemes in Colombia, they found that people who invested in Ponzi schemes have $39 \%$ more loans with formal financial system than those who did not. They found further that the collapse of Ponzi schemes increased non-performing loans by as much as $35 \%$.

\section{METHODOLOGY}

With the adoption of multi-stage probability sampling procedure, the researchers were able to select six (6) different states in Nigeria were selected to serve as the study area. In the first stage, the country was stratified into North and South of Nigeria, whereby, the southern part of Nigeria was purposively selected. In the second stage, the Southern part was stratified into the three (3) existing geo-political zones therefore, South- east, South-west and South- south. Finally, in third stage, two (2) states each were purposively selected out of the concerned geopolitical zones, which are Lagos and Ondo State in the south-west, Rivers and Delta State in the South-south as well as Abia and Anambra State in the South-East.

The structured questionnaires were administered to residents in the selected states. The list of the most participated Ponzi schemes were obtained from Nigeria citizens with the aid of questionnaire which was duly attached. The study population is the total number of people that participated before the fall of MMM and also people that are currently participating in other Ponzi Schemes in the states. In determining the sample size, Cochran (1963) formula, with confidence level of $95 \%$ was used which required a sample size of 64 respondents per state under study. Snowball technique was adopted for questionnaire administration to Ponzi scheme participants in the selected states. The proportionate distribution of the sample size in the selected states is shown in Table 1 as derived from equation:

$$
\mathrm{n}_{\mathrm{o}}=\frac{\mathrm{Z}^{2} \mathrm{pq}}{\mathrm{e}^{2}}
$$

where,

$\mathrm{n}_{\mathrm{o}}=$ sample size

$\mathrm{Z}^{2}=$ abscissa of the normal curve that cuts off an area $\alpha$ at the tails

$\mathrm{P}=$ estimated proportion of an attribute that is present in the population

$q=(1-\alpha)$ the desired confidence level

$\mathrm{e}^{2}=$ desired level of precision

TABLE 1: Number of Questionnaire to be administered in each of the States

\begin{tabular}{lll}
\hline State & Geo-political Zone & Number of Questionnaire \\
Ondo & South west & 64 \\
Lagos & South west & 64 \\
Rivers & South south & 64 \\
Delta & South south & 64 \\
Abia & South east & 64 \\
Anambra & South east & 64 \\
Total & & $\mathbf{3 8 4}$ \\
\hline
\end{tabular}

Source: Researchers' Compilation, 2018

This study employed the multivariate estimation technique to test the influence of demographic variables on Ponzi Schemes' participation. The data obtained from the structured questionnaires administered were coded and descriptive statistical techniques were employed 
with the use of ANOVA, Scheffe's Post Hoc Range Test, Omega square test, percentages, frequencies, mean and standard deviation.

The demographic variables were proxied as: Location- measured by the three geopolitical zones identified by the study; Age- measured by age group from ages 16 to 65+; Gendermeasured as participants being either male or female; Marital status- measures as single, married or divorced; Employment status- measured by full time, part-time or no employment status; and educational level- measured as the highest educational qualification of ponzi scheme participants.

\section{DATA PRESENTATION AND ANALYSIS}

\section{Demographic Characteristics of the Respondents}

The socio-economic characteristics of the respondents that participated in the Ponzi scheme survey are presented in Table 2.

TABLE 2: Respondents' Demographic Characteristics

\begin{tabular}{|c|c|c|c|}
\hline Variables & Respondents' Grouping $(n=359)$ & Frequency & Percent \\
\hline \multirow{6}{*}{ Location } & Abia & 63 & 17.5 \\
\hline & Anambra & 55 & 15.3 \\
\hline & Rivers & 61 & 17.0 \\
\hline & Delta & 63 & 17.5 \\
\hline & Ondo & 55 & 15.3 \\
\hline & Lagos & 62 & 17.3 \\
\hline \multirow{6}{*}{ Age } & $18-25$ & 109 & 30.4 \\
\hline & $26-35$ & 143 & 39.8 \\
\hline & $36-45$ & 57 & 15.9 \\
\hline & $46-55$ & 35 & 9.7 \\
\hline & $56-65$ & 9 & 2.5 \\
\hline & 66 and above & 6 & 1.7 \\
\hline \multirow[t]{2}{*}{ Gender } & Male & 206 & 57.4 \\
\hline & Female & 153 & 42.6 \\
\hline \multirow{3}{*}{ Marital Status } & Single & 193 & 53.8 \\
\hline & Married & 156 & 43.5 \\
\hline & Divorced & 10 & 2.8 \\
\hline \multirow{4}{*}{ Employment status } & Permanent full-time job & 79 & 22.0 \\
\hline & Permanent part-time job & 41 & 11.4 \\
\hline & Self employed & 122 & 34.0 \\
\hline & Student/Unemployed/Retired & 117 & 32.6 \\
\hline \multirow{5}{*}{ Educational Background } & Less than high school & 12 & 3.3 \\
\hline & High school or equivalent & 51 & 14.2 \\
\hline & Diploma/High Diploma & 84 & 23.4 \\
\hline & College/Bachelor & 141 & 39.3 \\
\hline & Graduate degree (Master's or PhD) & 71 & 19.8 \\
\hline
\end{tabular}

\section{Source: Researchers' Compilation, 2018}

As shown in Table 2 above, 32.8\% of the respondents are from the South-eastern part of Nigeria (Abia and Anambra), 34.5\% from South-south (Rivers and Delta) and the remaining 32.6\% from South-west (Ondo and Lagos). Abia and Delta states both share the highest percentage of respondents (17.5\% each) amongst the six states in the survey. The age profile of 
the respondents depicts that many of the respondents (39.8\%) were in the age category of 25 35 years, $30.4 \%$ were in the age category of $18-25$ years and $15.9 \%$ were in the bracket of 36 45 years. The results of the age distribution show that most participants in the Ponzi scheme in Nigeria are youths (ages 18 - 35 years) and that the holder populace is less willing to take the risks involved in the Ponzi scheme. The gender profile of the respondents also reveals that $57.4 \%$ are male while $42.6 \%$ are female. These two values are close, which may suggest that gender has little or no influence on participation in the scheme.

A larger percentage of the respondents in the survey are single (53.8\%), while the married accounted for $43.5 \%$ and the divorced, $2.8 \%$. This is in agreement with the age profile of the respondents, where we have the largest percentage to be youths. Besides, singles are known to take more financial risks, especially in the area of investment because it is generally assumed in the country, that they have little or no responsibilities. A married person will normally weigh options available, and probably consider the well-being of his dependents, becoming investing. The distribution of the employment status of the respondents reveals that most of the participants are either self-employed (34\%) or students/unemployed/retired (32.6\%). Those in permanent, full-time job accounted for $22 \%$, while the remaining $11.4 \%$ is for the permanent, part-time workers. Interestingly, the table also shows that most of the respondents are highly educated and thus well informed of the operations of the Ponzi scheme, with 39.3\% having College/Bachelor degrees, 23.4\% with Diploma degrees and 19.8\% with Graduate degrees. Only $3.3 \%$ of the respondents have less than high school certificates.

\section{Prioritization of Factors Influencing Participation in Ponzi Schemes}

Table 3 presents the mean and the standard deviation of some of the factors identified as influencing people's participation in Ponzi schemes in Nigeria. The results showed the five (5) most influencing factors influencing participation in ponzi schemes in Nigeria in order of importance and the (5) least influencing factors (with respect to their means and standard deviations):

TABLE 3: Factors Influencing Participation in Ponzi Schemes

\begin{tabular}{|l|l|l|l|}
\hline $\mathbf{S} / \mathbf{N}$ & Factors & Mean (M) & $\begin{array}{l}\text { Standard } \\
\text { Deviation (SD) }\end{array}$ \\
\hline $\mathbf{1}$ & Friend Recommendations & 3.4401 & 1.1824 \\
\hline $\mathbf{2}$ & Expected Benefits & 3.3983 & 1.2305 \\
\hline $\mathbf{3}$ & Current Economic Situations & 3.3649 & 1.2295 \\
\hline $\mathbf{4}$ & Ease of Obtaining Funds & 3.3315 & 1.1765 \\
\hline $\mathbf{5}$ & “Get rich quick" & 3.2535 & 1.2622 \\
\hline $\mathbf{6}$ & $\begin{array}{l}\text { Testimonials on Schemes' involvement in solving } \\
\text { people's problem }\end{array}$ & 3.1699 & 1.1635 \\
\hline $\mathbf{7}$ & Personal Judgement & 3.1142 & 1.2622 \\
\hline $\mathbf{8}$ & Past Performance of the Scheme & 3.0724 & 1.2123 \\
\hline $\mathbf{9}$ & Family member (s) opinion & 2.9109 & 1.2181 \\
\hline $\mathbf{1 0}$ & Perceived ethics of the Scheme & 2.9025 & 1.0980 \\
\hline & & 2018 & \\
\hline
\end{tabular}

Source: Researchers' Compilation, 2018

Friend's recommendations $(M=3.4401 ; S D=1.1824)$ ranking first and has the most influence on participation. This position is not farfetched as most of the schemes are modeled as a pyramid scheme where referral attracts some form of bonuses. Expected benefits $(M=3.3983 ; S D=$ 1.2305) ranked second, implying that people's expectation on returns from participation is the second most influencing factor encouraging participation in ponzi schemes; Current economic 
situation is the third most influencing factor on participation in ponzi scheme $(M=3.3649 ; S D=$ 1.2295). This position is in line with the study of Asogwa et al, 2017 as economic recession, inflation, rising unemployment etc. are seen as economic factors contributing to people's decision to get involved in ponzi schemes.

The ease of obtaining fund is the fourth most influencing factors on participation in ponzi scheme participation $(M=3.3315 ; S D=1.1765)$. This is the case because people assume that it is easier to get funds for business/personal purposes through ponzi schemes than the formal financing arrangements. In addition, the "get rich quick" syndrome is the fifth most influencing factor on people's involvement in ponzi scheme $(M=3.2535 ; S D=1.2622)$ implying that ponzi scheme attracts huge participation as an average participant has the intention to make money as quick as possible.

The least influencing factors on participation in ponzi schemes in Nigeria according to the findings in this study includes: the perceived ethic of the scheme; family member(s) opinion; past performance of the scheme; personal judgment; and testimonials on schemes' involvement in solving people's problems.

\section{Results of the ANOVA and Post Hoc Tests of factors influencing participation in Ponzi scheme}

The effects of the demographic characteristics of respondents on the factors influencing their participation in Ponzi scheme were analyzed in this section.

\section{Location and factors influencing participation in Ponzi scheme}

Table 4 showed a one way ANOVA test between the location of respondents and the five most influencing factors for participation in the Ponzi scheme.

TABLE 4: Influence of Location on the five most influencing factor on Ponzi Scheme

\begin{tabular}{|l|c|c|c|c|c|}
\hline Between groups & Sum of Squares & df & Mean Square & F & Sig. \\
\hline Friend's Recommendation & 126.04 & 79 & 1.60 & 1.19 & 0.157 \\
\hline Expected Benefits & 161.80 & 79 & 2.05 & 1.50 & 0.009 \\
\hline Current Economic Situations & 127.62 & 79 & 1.62 & 1.09 & 0.304 \\
\hline Ease of Obtaining Funds & 116.57 & 79 & 1.48 & 1.09 & 0.310 \\
\hline "Get rich quick" & 130.76 & 79 & 1.66 & 1.12 & 0.256 \\
\hline
\end{tabular}

Source: Researchers' Compilation, 2018

The results of the ANOVA show that there was a statistically significant difference among the different locations and only one of the five most influencing factors; "expected benefits" $(F=$ 1.50, $p=0.009$ ), at five percent significance level. The remaining factors, 'friend's recommendation" ( $F=1.19, p=0.157$ ), "current economic situation" ( $F=1.09, p=0.304$ ), "ease of obtaining funds" ( $F=1.09, p=0.310)$ and "get rich quick" $(F=1.12, p=0.256)$ are statistically insignificantly different.

\section{Age and factors influencing participation in Ponzi scheme}

Table 5 showed a one way ANOVA test between the age of respondents and the five most influencing factors in Ponzi scheme participation. 
TABLE 5: Influence of Age on the five most influencing factors on Ponzi Scheme participation

\begin{tabular}{|c|c|c|c|c|c|}
\hline Between groups & Sum of Squares & df & Mean Square & $\mathbf{F}$ & Sig. \\
\hline Friend's Recommendation & 10.60 & 5 & 2.12 & $\begin{array}{c}1.5 \\
3\end{array}$ & 0.181 \\
\hline Expected Benefits & 8.49 & 5 & 1.70 & $\begin{array}{c}1.1 \\
2\end{array}$ & 0.348 \\
\hline Current Economic Situations & 9.61 & 5 & 1.92 & $\begin{array}{c}1.2 \\
8 \\
\end{array}$ & 0.274 \\
\hline Ease of Obtaining Funds & 13.82 & 5 & 2.76 & $\begin{array}{c}2.0 \\
3\end{array}$ & 0.075 \\
\hline "Get rich quick" & 7.47 & 5 & 1.49 & $\begin{array}{c}0.9 \\
8 \\
\end{array}$ & 0.428 \\
\hline
\end{tabular}

Source: Researchers' Compilation, 2018

The results of the ANOVA above show that there was no significant difference among the various age groups and the five most influencing factors on Ponzi scheme participation, at five percent level of significance; 'friend's recommendation" $(F=1.53, p=0.181)$, "expected benefits" ( $F=1.12, p=0.348)$, "current economic situation" $(F=1.28, p=0.274)$, "ease of obtaining funds" $(F=2.03, p=0.075)$ and "get rich quick" ( $F=0.98, p=0.428)$.

TABLE 6: Dependent Variable: Ponzi Scheme Participation

\begin{tabular}{|lll|}
\hline AGE & Mean & Std. Dev. \\
\hline $18-25$ & 3.42 & 1.19 \\
\hline $26-35$ & 3.69 & 1.22 \\
\hline $36-45$ & 3.79 & 1.03 \\
\hline $46-55$ & 3.40 & 1.24 \\
\hline $56-65$ & 3.30 & 0.87 \\
\hline 65 and More & 3.67 & 1.21 \\
\hline
\end{tabular}

Source: Researchers' Compilation, 2018

The summary of Scheffe's post hoc range test was used to identify homogeneous subset of mean age and its influence on ponzi scheme participation. The results in Table 6 indicate that participants within the age range 36-45 influenced ponzi scheme participation than any other age group with a mean of 3.79 followed by participants within the age group 26-35. These age groups have the most influence on ponzi scheme participation. However, the age influence is not statistically significant with ponzi scheme participation in Nigeria.

\section{Gender and Factors influencing participation in Ponzi scheme}

Table 7 depict a one way ANOVA test between the gender of the respondents and the five most influencing factors in Ponzi scheme participation.

TABLE7: Influence of Gender on the five most influencing factors on Ponzi Scheme participation

\begin{tabular}{|l|c|c|c|c|c|}
\hline \multicolumn{1}{|c|}{ Between groups } & Sum of Squares & df & Mean Square & F & Sig. \\
\hline Friend's Recommendation & 5.45 & 2 & 2.73 & 1.96 & 0.142 \\
\hline Expected Benefits & 3.11 & 2 & 1.56 & 1.03 & 0.359 \\
\hline Current Economic Situations & 10.27 & 2 & 5.14 & 3.44 & 0.033 \\
\hline Ease of Obtaining Funds & 0.60 & 2 & 0.30 & 0.21 & 0.807 \\
\hline "Get rich quick" & 3.18 & 2 & 1.59 & 1.05 & 0.353 \\
\hline
\end{tabular}




\section{Source: Researchers' Compilation, 2018}

The results of the ANOVA show that the difference between gender and "Current Economic Situations" as factor influencing Ponzi scheme, is statistically significant at five percent level of significant $(F=3.44, p=0.033)$. However, this difference is not statistically significant for the other four most influencing factors.

TABLE 8: Dependent Variable: Ponzi Scheme Participation

\begin{tabular}{|lll|}
\hline Gender & Mean & Std. Dev. \\
\hline Male & 3.52 & 1.13 \\
\hline Female & 3.33 & 1.25 \\
\hline
\end{tabular}

Source: Researchers' Compilation, 2018

The results in Table 8 from the summary of Scheffe's Post Hoc test indicate that male participants influenced ponzi scheme participation more than female participants with a mean of 3.52. This shows that Nigerian men participated more in ponzi scheme because of the current economic situation of the country.

\section{Marital Status and Factors influencing participation in Ponzi scheme}

A one way ANOVA test between the marital status of the respondents and the five most influencing factors in Ponzi scheme participation is presented in Table 9.

TABLE 9: Influence of Marital Status on the five most influencing factors

\begin{tabular}{|l|c|c|c|c|c|}
\hline Between groups & Sum of Squares & Df & Mean Square & F & Sig. \\
\hline Friend's Recommendation & 14.09 & 3 & 4.70 & 3.43 & 0.017 \\
\hline Expected Benefits & 5.90 & 3 & 1.97 & 1.31 & 0.272 \\
\hline Current Economic Situations & 10.65 & 3 & 3.55 & 2.37 & 0.070 \\
\hline Ease of Obtaining Funds & 2.50 & 3 & 0.83 & 0.60 & 0.614 \\
\hline "Get rich quick" & 21.85 & 3 & 7.28 & 4.97 & 0.002 \\
\hline
\end{tabular}

Source: Researchers' Compilation, 2018

The results of the ANOVA show that there is a statistically significant difference among the various marital status of respondents and two of the five most influencing factors; friend recommendation ( $F=3.43, p=0.017)$ and "get rich quick" ( $F=4.97, p=0.002)$, at five percent significant level.

To measure the strength of association (omega square, $\omega^{2}$ ) between the independent variable and the dependent variable, since there is a significant $F$, from the one way analysis of variance of the effect of the marital status of respondent on the most influencing factor of Ponzi scheme participation, "friend's recommendation" ( $F=3.43, p=0.017)$, the omega square is calculated as

$$
\begin{aligned}
\text { Omega square }\left(\omega^{2}\right) & =\mathrm{SS}_{\mathrm{B}}-(\mathrm{K}-1) \mathrm{MS}_{\mathrm{W}} /\left(\mathrm{SS}_{\mathrm{T}}+\mathrm{MS}_{\mathrm{W}}\right) \\
& =14.09-(3-1) 1.3671 /(483.9370+1.3671) \\
& =11.3558 / 485.3041=0.023
\end{aligned}
$$

The results indicated that the independent variable (marital status) accounts for approximately $2.3 \%$ of the variance in the dependent variable (friend's recommendation) of the respondents.

TABLE 10: Dependent Variable: Ponzi Scheme Participation

Marital Status Mean $\quad$ Std. Dev.




\begin{tabular}{|lll|}
\hline Single & 3.54 & 1.24 \\
\hline Married & 3.66 & 1.09 \\
\hline Divorced & 3.25 & 0.76 \\
\hline
\end{tabular}

Source: Researchers' Compilation, 2018

The summary of Scheffe's Post Hoc test carried out on the influence of marital status on ponzi scheme participation in Table 9 show that married participants influenced ponzi scheme participation with a mean of 3.66 followed by singles with a mean of 3.54. This shows that married men participated more in ponzi scheme because of the current economic situation of the country, friends' recommendations and the 'get rich quick' syndrome.

\section{Employment Status and Factors influencing participation in Ponzi scheme}

Table 11 depict a one way ANOVA test between the employment status of the respondents and the five most influencing factors in Ponzi scheme participation.

TABLE 11: Influence of Employment Status on the five most influencing factors

\begin{tabular}{|l|c|c|c|c|c|}
\hline \multicolumn{1}{|c|}{ Between groups } & Sum of Squares & df & Mean Square & F & Sig. \\
\hline Friend's Recommendation & 15.58 & 3 & 5.19 & 3.80 & 0.011 \\
\hline Expected Benefits & 8.77 & 3 & 2.92 & 1.95 & 0.122 \\
\hline Current Economic Situations & 5.93 & 3 & 1.98 & 1.31 & 0.270 \\
\hline Ease of Obtaining Funds & 4.86 & 3 & 1.62 & 1.17 & 0.320 \\
\hline "Get rich quick" & 20.43 & 3 & 6.81 & 4.62 & 0.004 \\
\hline
\end{tabular}

Source: Researchers' Compilation, 2018

The ANOVA results above reveal that there is a statistically significant difference among the various employment status of respondents an two of the five most influencing factors; "friend recommendation" ( $F=3.80, p=0.011)$ and "get rich quick" $(F=4.62, p=0.004)$, at five percent significant level.

To measure the strength of association (omega square, $\omega^{2}$ ) between the independent variable and the dependent variable, since there is a significant $F$, from the one way analysis of variance of the effect of the employment status of respondent on the most influencing factor of Ponzi scheme participation, "friend's recommendation" $(F=3.80, p=0.011)$, the omega square is calculated as

$$
\text { Omega square } \begin{aligned}
\left(\omega^{2}\right) & =\mathrm{SS}_{\mathrm{B}}-(\mathrm{K}-1) \mathrm{MS}_{\mathrm{W}} /\left(\mathrm{SS}_{\mathrm{T}}+\mathrm{MS}_{\mathrm{W}}\right) \\
& =15.58-(4-1) 1.3659 /(484.8806+1.3659) \\
& =11.4823 / 486.246=0.024
\end{aligned}
$$

The results indicated that the independent variable (four employment status) accounts for approximately $2.4 \%$ of the variance in the dependent variable (friend's recommendation) of the respondents.

TABLE 12: Dependent Variable: Ponzi Scheme Participation

\begin{tabular}{|lll|}
\hline Employment Status & Mean & Std. Dev. \\
\hline Permanent full-time job & 3.68 & 0.98 \\
\hline Permanent part-time job & 3.80 & 1.08 \\
\hline Self employed & 3.34 & 1.26 \\
\hline Student/ Unemployed/ Retired & 3.25 & 1.22 \\
\hline
\end{tabular}




\section{Source: Researchers' Compilation, 2018}

The summary of Scheffe's post hoc range test was used to identify homogeneous subset of employment status and its influence on ponzi scheme participation. The results in Table 12 indicate that participants with permanent part-time job influenced participation in ponzi scheme with a mean of 3.80. Those with permanent full-time job were seen to also influence ponzi scheme participation with the mean 3.68.

\section{Educational Level and Factors influencing participation in Ponzi scheme}

Table 13 depict a one way ANOVA test between the educational level of the respondents and the five most influencing factors in Ponzi scheme participation.

TABLE 13: Influence of Educational Level on the five most influencing factors

\begin{tabular}{|l|c|c|c|c|c|}
\hline Between groups & Sum of Squares & df & Mean Square & F & Sig. \\
\hline Friend's Recommendation & 33.66 & 5 & 6.73 & 5.13 & 0.000 \\
\hline Expected Benefits & 18.42 & 5 & 3.68 & 2.50 & 0.031 \\
\hline Current Economic Situations & 29.29 & 5 & 5.86 & 4.06 & 0.001 \\
\hline Ease of Obtaining Funds & 21.40 & 5 & 4.28 & 3.22 & 0.008 \\
\hline "Get rich quick" & 9.64 & 5 & 1.93 & 1.29 & 0.270 \\
\hline
\end{tabular}

Source: Researchers' Compilation, 2018

The results of the ANOVA test above show that there is a statistically significant difference among the various level of education and almost all the five most influencing factors, at five percent significant level, except the "get rich quick" factor; "friend recommendation" ( $F=5.13$, $p=0.000)$, expected benefits $(F=2.50, p=0.031)$, "current economic situation" $(F=4.06, p=$ 0.001), "ease of obtaining funds" ( $F=3.22, p=0.008)$. This shows that Educational level is a factor affecting participation in Ponzi scheme in Nigeria.

To measure the strength of association (omega square, $\omega^{2}$ ) between the independent variable and the dependent variable, since there is a significant $F$, from the one way analysis of variance of the effect of the educational level of respondent on the most influencing factor of Ponzi scheme participation, "friend's recommendation" $(F=5.13, p=0.000)$, the omega square is calculated as

$$
\text { Omega square } \begin{aligned}
\left(\omega^{2}\right) & =\mathrm{SS}_{\mathrm{B}}-(\mathrm{K}-1) \mathrm{MS}_{\mathrm{W}} /\left(\mathrm{SS}_{\mathrm{T}}+\mathrm{MS}_{\mathrm{W}}\right) \\
& =33.66-(5-1) 1.3211 /(465.0277+1.3211) \\
& =28.3756 / 466.3488=0.061
\end{aligned}
$$

The results indicated that the independent variable (five levels of education) accounts for approximately $6.1 \%$ of the variance in the dependent variable (friend recommendation) of the respondents.

TABLE 14: Dependent Variable: Ponzi Scheme Participation

\begin{tabular}{|lll|}
\hline Educational level & Mean & Std. Dev. \\
\hline Less than high school & 3.01 & 1.41 \\
\hline High school or equivalent & 3.51 & 1.10 \\
\hline Diploma/High Diploma & 3.37 & 1.20 \\
\hline College/Bachelor & 3.57 & 1.04 \\
\hline Graduate degree (Master's or Ph.D) & 3.43 & 1.29 \\
\hline
\end{tabular}




\section{Source: Researchers' Compilation, 2018}

Table 13 indicate the summary of Scheffe's Post Hoc test carried out on the influence of educational level on ponzi scheme participation show that College/Bachelors degree holders influenced ponzi scheme participation more with a mean of 3.57 followed by High school graduates with a mean of 3.51

\section{SUMMARY OF FINDINGS, CONCLUSION AND RECOMMENDATIONS}

After due analysis of the study, the main findings are as follows:

i. The five most influencing factors in ponzi scheme participation in Nigeria as identified are; friend's recommendation, expected benefits, current economic situations, ease of obtaining funds and Get rich quick syndrome.

ii. The demographic characteristic of the respondents (location, age, gender, marital status, employment status and educational level) have statistically significant influence on ponzi scheme participation in Nigeria.

iii. With regards to the friend recommendation as an assessing factor, respondents statistically differed in factor assessment for marital status, employment status and educational level.

iv. The results of the analysis show that most participants in the ponzi scheme in Nigeria are youth and that the older populace is less willing to take the risks involved in ponzi scheme.

In conclusion, ponzi scheme participation is mostly influenced by certain identified factors which are friend's recommendation, expected benefit, current economic situations, ease of obtaining funds and Get rich quick syndrome. These factors are significantly influenced by location, gender, marital status, employment status and educational level (which has the most influence) on ponzi scheme participants in Nigeria. Furthermore, married men with degrees and employment are mostly influenced by the assessing factors of ponzi scheme participation.

Based on the findings of this study, it is recommended that Nigerian government should integrate Ponzi schemes into the Nigerian financial system and subject them to the country's regulatory environment to minimize the consequences of future failure of the schemes.

\section{References}

Asogwa, I. E., Etim, E. O., Etukafia, N. I., Akpanuko, E. E. and Ntiedo, B. E. (2017). Synopsis of Nigerian Economy and the Growth of Ponzi Schemes. Global Journal of Management and Business Research: Economics and Commerce. 17 (3), 44-54

Aurora, M. (2017). Top 7 Current Ponzi Schemes in Nigeria 2017, https://www.oasdom.com/7-current-ponzischemes-nigeria-2017/

Azim, M. I. and Azam, S. (2016). Bernard Madoff's 'Ponzi Scheme': Fraudulent Behaviour and the Role of Auditors. Accountancy Business and the Public interest. 1(1), 122-137

Bartoletti, M., Carta, S., Cimoli, T., Saia R. (2017). Dissecting Ponzi Schemes on Etherum: Identification, Analysis and Impact. Dipartimento di Matematica e Informatica- Universita di Cagliari. 1-33

Behind MLM, (2017). Claritta Review: 4×1 Matrix Ponzi Cash Gifting, Retrieved from: http://behindmlm.com/mlm-reviews/claritta-review-4x1-matrix-ponzi-cash-gifting/

Benson, S. S. (2009). Recognizing the Red Flags of a Ponzi Scheme. The CPA Journal, 79 (6), 18-25

Bhattacharya, U. (1998). On the Possibilities of Ponzi Scheme in Transition Economies. Kelly School of Business, Indiana Unkiversity, Bloomington, 1-38

Buchholz, K. A. (2012). SAS 99: Deconstructing the Fraud Triangle and Some Classroom Suggestions. Journal of Leadership, Accountability and Ethics, 9 (2), 105-121 
Calendergist, (2017). Changing Lives Online (Register on CLO and Get 100\% in 24hours), Retrieved from: http://calendergist.com.ng

Carvajal, A., Monroe, H., Wynter, B., \& Pattillo, C. A. (2009). Ponzi in the Caribbean.

Cass, R. A. (2008). Madoff Exploited the Jews. The Wall Street Journal, December 18, A 19

Cherry, M. A., \& Wong, J. (2009). Clawbacks: Prospective Contract Measures in an Era of Excessive Executive Compensation and Ponzi Schemes Minn. L. Rev., 94, 368.

Cortés, D., Santamaría, J., \& Vargas, J. F. (2016). Economic shocks and crime: Evidence from the crash of Ponzi schemes. Journal of EconomicBehavior \& Organization, 131, 263-275.

Cressey, D. R. (1953). Other People's Money. Montclair, New Jersey: Patterson Smith, 1-300

Day, R. (2010). Applying the Fraud Triangle Model to the Global Credit Crisis. Nordicum-Mediterraneum, 5(1), B8

Drew, J. M., \& Drew, M. E. (2010). The identification of Ponzi schemes: can a picture tell a thousand frauds? Griffith Law Review, 19(1), 51-70.

Edino, J. (2016).NNN Nigeria: The Rise of Ponzi Empires, NTA official Website, Retrieved from:

http://www.nta.ng/news/domestic/20161218-nnn-nigeria-rise-ponzi-empires/

Fatunde T., (2017). Students emerge as prime targets for Ponzi fraud University World News Retrieved from http://www.universityworldnews.com/article.php?story $=20170318062151892$

Gregoriou, G. N., \& Lhabitant, F. S. (2009). Madoff: A riot of red flags. The Journal of Wealth Management, 12(1), 8997.

Hofstetter, M., Mejía, D., Rosas, J. N., \& Urrutia, M. (2017). Ponzi Schemes and the Financial Sector: DMG and DRFE in Colombia.

Ibenegbu, G. (2017). History of Get Help Worldwide, naij.ng platform, retrieved

from: https://www.naija.ng/1094593-history-get-help-worldwide.html\#1094593

Jacobs, P. and Schain, L. (2011). The Never Ending Attraction of the Ponzi Scheme. Journal of Comprehensive Research, 9, 40-46

Kashi, V. (2017). List of All Ponzi Schemes Sites in Nigeria 2017, Retrieved from: www.entclass.com.ng/2017/02/ponzi-schemes-sites-list-nigeria.html\#ixzz4y5VaUHGV

Krige, D. (2012). Fields of dreams, fields of schemes: Ponzi Finance and Multi-Level Marketing in South Africa. Africa, 82(1), 69-92. https://www.vanguardngr.com/2016/12/mmm-affects-banks-bankers/

Kumolu C. (2016, December 13). Money-doubling trouble: Nigerians fight over MMM.Vanguard.Retrievedfrom:https://www.vanguardngr.com/2016/12/nigerians-fight-over-mmm.

Lami O. (2017). Impacts of Ponzi Schemes on Nigeria economy.

InfoGuideNigeria.com.Retrievedfrom:https://infoguidenigeria.com/impacts-of-ponzi-schemes-on-nigeriaeconomy

Ogunlana, M. (2017). Why You Should Not Invest in 247helpers Ponzi Scheme, Page one Official website,

Retrieved from: https://www.pageone.ng

Omanyo, R. (2017). An Assessment of Ponzi schemes in Kenya among the Financial Market Players. A Project Report: University States International University Africa, 1-73

Ponzi schemes in the Caribbean. Cantoni, C. J. (2009). A Brief History of Ponzi Schemes. Journal of American Physicians and Surgeons. 14, 24

Quisenberry, W. L. (2017). Ponzi of All Ponzis: Critical Analysis of the Bernie Madoff Scheme. International Journal of Econometrics and Financial Management, 5(1), 1-6

Rhee, R. J. (2009). The Madoff scandal, market regulatory failure and the business education of lawyers. Journal of Corporation Law, 35, 363.

Rowe, B. R. (2000). Ponzi Schemes. Utah State University Extension Financial Fitness Fact Sheet. 1-2 ScamBitcoin, (2017). BTC Investments Review - A Bitcoin Gifting Pyramid Scheme, Retrieved from: https://www.scambitcoin.com

Shibayan, D. (2017).New Ponzi Scheme Emerges, Lures Participants With 200\% 'Interest', The Cable.Ng, Retrieved from:https://www.thecable.ng/twinkas-new-ponzi-scheme-emerges-promises-participants-200-percent-oninvestmen 
Simon E.S. (2017, December 13). Why Ponzi schemes thrive in Nigeria despite 18bn loss to MMM. DAILY TRUST Newspaper. Retrieved from https://www.dailytrust.com.ng/news/business/why-ponzi-schemes-thrive-innigeria-despite-n18bn-loss-to-mmm/193775.html

Slattery T. (2014). Taking a bit out of crime: Bitcoin abd cross-broder tax evasion. Brook J. International L. 39,829

Smith, F. (2010). Madoff Ponzi Scheme Exposes the Myth of the Sophisticated Investor. University of Baltimore Law Review, 40, 215.Reasons why Ponzi collapse Dave Meyer June 52012 Online Daily 2017

Telegraph Reporters, Bernard Madoff: What is a Ponzi Scheme and How Does It Work? Online Business News,http://www.telegraph.co.uk/business/0/bernard-madoff-ponzi-scheme-does-work/

Thanasi, E. and Riotto, J. (2017). The Spectacular Rise and Disastrous Collapse of a Financial Scheme: The Case of Albania. Open Journal of Business and Management, 5, 194-207

Walsh, J. (1999) How Ponzi Schemes, Pyramid-Fraud, Work. Consumers Research, 6: 10-14

Wilkins, A. M., Acuff, W. W. and Hermanson, D. R. (2012). Understanding a Ponzi Scheme: Victims' Perspectives. Journal of Forensic \& Investigative Accounting, 4 (1), 1-19 